(Житомирський державний університет імені Івана Франка) dmitry_antonyukezu.edu.ua ORCID: $0000-0001-7496-3553$

\title{
ЕФЕКТИВНІСТЬ ВИКОРИСТАННЯ ПРОГРАМНО-ІМІТАЦІЙНИХ КОМПЛЕКСІВ ЯК ЗАСОБУ ФОРМУВАННЯ ЕКОНОМІЧНОЇ КОМПЕТЕНТНОСТІ СТУДЕНТІВ ТЕХНІЧНИХ СПЕЦАЛЬНОСТЕЙ ЗА РЕЗУЛЬТАТАМИ ПЕДАГОГІЧНОГО ЕКСПЕРИМЕНТУ
}

\author{
У статті представлено результати педагогічного експерименту щзодо ефективності використання \\ програмно-імітаційних комплексів як засобу формування економічної компетентності студентів \\ технічних спеціальностей. Згідно з отриманими даними, запропонована методика виявилася \\ ефективною, оскільки спостерігається зростання рівня сформованості економічних компетентностей \\ студентів технічних спеціальностей.
}

Ключові слова: педагогічний експеримент, ефективність, економічна компетентність.

Постановка проблеми. Інформаційно-комунікаційні технології стали невід'ємною частиною існування сучасного суспільства. Після виходу з наукового середовища, що їх створює, сучасні розробки в більшості напрямків діяльності людини, в першу чергу, потрапляють у комерційну та розважальну галузі, що забезпечують творцям найбільший прибуток. У той же час, освіта в більшості країн, через ряд об'єктивних і суб'єктивних, економічних, соціальних та політичних причин, відстає у використанні сучасних технічних, технологічних і психологічних досягнень людства.

Так, програмно-імітаційні комплекси економічного спрямування використовуються компаніями та державними інституціями для аналізу поточного стану та прогнозування тенденцій розвитку організацій приватного та державного секторів, галузей економіки, країн та світу в цілому. Провідні навчальні заклади світу використовують такі комплекси для закріплення умінь та навичок майбутніх економістів та управлінців.

Сучасний стан та напрямок розвитку економіки України вимагає від спеціалістів технічних спеціальностей не лише знань безпосередньо в галузі їх навчання, а також теоретичного розуміння принципів функціонування економіки країни і світової економічної системи на мікро- та макрорівнях, наявності базових умінь i навичок використання економічних принципів у своїй повсякденній професійній діяльності. Такі знання і вміння нададуть технічним спеціалістам можливість скеровувати свою технічну та творчу діяльність згідно економічних можливостей та потреб країни, враховуючи перспективи розвитку суспільства в цілому. Також, необхідним є формування економічних компетентностей спеціалістів із вищою освітою для використання в побуті.

Аналіз основних досліджень і публікацій. Застосування програмно-імітаційних комплексів створює умови для інтеграції аудиторної та позааудиторної роботи із застосуванням методів змішаного (комбінованого) навчання, можливості та протиріччя якого висвітлювали в своїх працях Д. Берн (D. Byrne), К. Дж. Бонк (C. J. Bonk), Н. Д. Воган (N. D. Vaughan), Д. Р. Гарpicoн (D. R. Garrison), Ч. Р. Грехам (C. R. Graham), Б. Колліс (B. Collis), В. М. Кухаренко, С. М. Смирнова-Трибульска, П. В. Стефаненко, Ю. В. Триус, Б.І. Шуневич та ін.

Безпосереднє застосування програмно-імітаційних комплексів у процесі навчання розглядали В. Адамс (W. K. Adams), Б. Девейн (В. Devine), Е. Кастронова (Е. Castronova), К. Перкінс (K. Perkins), C. Фортман-Poe (S. Fortmann-Roe), в Україні дану тему досліджували О. О. Мацюк, В. А. Пермінова, О. Б. Шендерук. Дослідженням аспектів формування та розвитку економічних компетентностей займались О. П. Аменд, П. Г. Банщиков, В. В. Дивак, Д. О. Закатнов, В. Я. Паздрій та ін.

Незважаючи на те, що багато науковців-сучасників вивчали провідні ідеї з даного питання, не було детальних досліджень щодо ефективності використання програмно-імітаційних комплексів економічного спрямування в освітньому процесі ВНЗ.

Метою статті є з'ясувати на основі результатів педагогічного експерименту рівень ефективності використання програмно-імітаційних комплексів як засобу формування економічних компетентностей студентів технічних спеціальностей.

Виклад основного матеріалу. 3 метою перевірки ефективності розробленої методики використання програмно-імітаційних комплексів як засобу формування економічних компетентностей студентів технічних спеціальностей було проведено педагогічний експеримент.

Основним завданням педагогічного експерименту було підвищення рівня сформованості економічної компетентності студентів технічних спеціальностей засобами програмно-імітаційних комплексів у процесі навчання курсу "Принципи економіки".

Експериментальна робота щодо моделювання та впровадження авторської методики використання 
програмно-імітаційних комплексів як засобу формування економічних компетентностей студентів технічних спеціальностей проходила як педагогічний експеримент у три етапи (див. табл. 1).

Табличя 1.

Етапи виконання дослідження

\begin{tabular}{|c|l|l|}
\hline № & $\begin{array}{l}\text { Eman } \\
\text { досліджсення }\end{array}$ & 3міст \\
\hline 1 & $\begin{array}{l}\text { Констатувальний } \\
2013-2014 \text { рр. }\end{array}$ & $\begin{array}{l}\text { Визначення стану сформованості економічних компетентностей студентів } \\
\text { технічних спеціальностей. } \\
\text { Розроблення програми експериментального дослідження. }\end{array}$ \\
\hline 2 & $\begin{array}{l}\text { Пошуковий } \\
2015-2016 \text { р. }\end{array}$ & $\begin{array}{l}\text { Аналіз наявних ПІК економічного спрямування щодо можливості } \\
\text { використання в рамках дослідження та виділення критеріїв ї добору. } \\
\text { Створення моделі та методики використання ПІК як засобу формування } \\
\text { економічних компетентностей студентів технічних спеціальностей. }\end{array}$ \\
\hline 3 & $\begin{array}{l}\text { Формувальний } \\
\text { 2017-2018 рр. } \\
\text { Програція ПІК у навчальний процес за розробленою методикою. } \\
\text { студентів технічних спеціальностей. } \\
\text { Узагальнення та оформлення результатів }\end{array}$ \\
\hline
\end{tabular}

В рамках проведення дослідницько-експериментальної роботи автор брав участь у апробації та впровадженні основних положень дослідження: викладання курсу "Принципи економіки" в Житомирському державному технологічному університеті, проведення занять та воркшопів зі студентами, викладачами та фахівцями технічних та економічних спеціальностей. Також, автор приймав участь у розробці програмно-імітаційних комплексів економічного спрямування та організовував участь команд студентів у змаганнях, що проводились провідними компаніями-розробниками ПІК економічного спрямування.

Результати впровадження методики використання ПІК як засобу формування економічних компетентностей студентів технічних спеціальностей в усіх ВНЗ враховувались, статистично опрацьовувались лише результати впровадження методики в Житомирському державному технологічному університеті (ЖДТУ) у 2017-2018 н.р. на базі 144 студентів.

Контрольні та експериментальні групи під час проведення експерименту розподілялись за наступним принципом:

Контрольні групи (КГ) - студенти четвертого курсу бакалаврата ПІ-49-1, ПІ-50-1, студенти першого курсу магістерської програми ПІ-46м-1, ПІ-47м-1 та студенти другого курсу магістерської програми ПІ48м. Навчання даних груп здійснювалось за традиційною методикою 3 використанням традиційних форм, методів та засобів навчання.

Експериментальні групи (ЕГ) - студенти четвертого курсу бакалавріата ПІ-49-2, ПІ-50-2, студенти першого курсу магістерської програми ПІ-46м-2, ПI-47м-2, МІТ-2м. Навчання таких груп здійснювалось за розробленою методикою $з$ використанням нетрадиційних форм, широкого спектру методів та IКТорієнтованих засобів навчання (програмно-імітаційних комплексів економічного спрямування).

Забезпечення рівності умов проведення експерименту:

- навчання груп здійснювалось одним і тим самим викладачем;

- було визначено статистичну різнозначність груп на початку формувального етапу експерименту шляхом аналізу результатів оцінювання рівня сформованості економічних компетентностей студентів технічних спеціальностей з використанням Тесту на розуміння економіки в коледжі, 4-та редакція (Test of understanding in college economics, TUCE, Fourth Edition) який є однією з небагатьох розроблених методик тестування базового рівня економічних знань та умінь та Анкети для визначення рівня сформованості економічної компетентності студентів технічних спеціальностей за мотиваційним і особистісним критеріями.

На формувальному етапі педагогічного експеримента оцінювання рівня сформованості економічних компетентностей студентів відбувалось в процесі виконання контрольних теоретичних та практичних завдань МВОК, написання есе $з$ тематики, що вивчається та есе за темами економічних симуляцій, що проводилась під час лекційних та практичних робіт, опитування за результатами самостійного опрацювання матеріалу студентами, проходження анкетування для визначення рівня сформованості економічних компетентностей студентів технічних спеціальностей за мотиваційним і особистісним критеріями. Вимірювання рівнів сформованості економічних компетентностей студентів технічних спеціальностей здійснювалась за відповідністю наступним рівням: низький, середній, достатній, високий.

За результатами аналізу оцінок наведемо дані щодо рівнів прояву критеріїв сформованості економічних компетентностей студентів в експериментальних та контрольних групах на констатувальному та формувальному етапах педагогічного експерименту.

Результати аналізу рівня наведено в таблиці 2. 
Таблиия 2.

Дані контрольної та експериментальної груп за рівнями сформованості економічної компетентності

\begin{tabular}{|c|c|c|c|c|c|c|c|c|c|c|c|c|c|c|c|c|}
\hline \multirow{3}{*}{$\begin{array}{l}\text { Етап } \\
\text { Групи } \\
\text { Рівні }\end{array}$} & \multicolumn{8}{|c|}{ Констатувальний } & \multicolumn{8}{|c|}{ Формувальний } \\
\hline & \multicolumn{4}{|c|}{$\mathbf{E} \Gamma$} & \multicolumn{4}{|c|}{ КГ } & \multicolumn{4}{|c|}{$\mathbf{E} \Gamma$} & \multicolumn{4}{|c|}{ КГ } \\
\hline & 焉 & 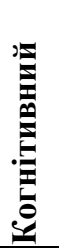 & 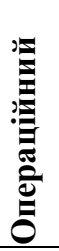 & 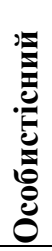 & 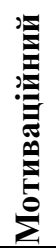 & 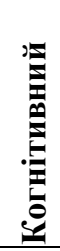 & ס & 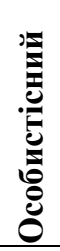 & 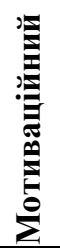 & 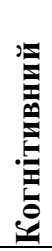 & ס & 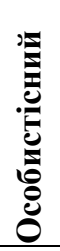 & 罢 & 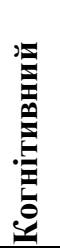 & 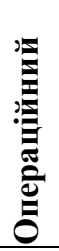 & 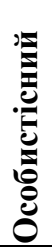 \\
\hline Низький & 22 & 23 & 26 & 22 & 26 & 24 & 25 & 24 & 12 & 9 & 8 & 10 & 12 & 11 & 12 & 12 \\
\hline Середній & 28 & 28 & 25 & 27 & 27 & 29 & 29 & 30 & 21 & 22 & 22 & 17 & 41 & 44 & 42 & 41 \\
\hline Достатній & 17 & 15 & 16 & 18 & 14 & 15 & 13 & 12 & 26 & 27 & 32 & 32 & 13 & 9 & 11 & 12 \\
\hline Високий & 5 & 6 & 5 & 5 & 5 & 4 & 5 & 6 & 13 & 14 & 10 & 13 & 6 & 8 & 7 & 7 \\
\hline
\end{tabular}

Проаналізуємо результати експерименту в розрізі окремих критеріїв сформованості економічних компетентностей.

Перевірка рівня сформованості економічних компетентностей за мотиваційним критерієм на формувальному етапі педагогічного експерименту відбувалась в процесі оцінки відвідування занять, оцінювання обгрунтувальної частини есе з окремих тем курсу, що відповідають певним симуляціям, що проводились в межах аудиторних форм організації освітнього процесу. Також, наприкінці курсу було проведено повторне анкетування студентів за тією ж самою анкетою.

Таблиця 2 та діаграма на рис. 1. показують, що в результаті застосування експериментальної методики використання програмно-імітаційних комплексів як засобів формування економічних компетентностей студентів технічних спеціфальностей відбулося збільшення відсотка студентів експериментальної групи у порівнянні із відсотком студентів в Контрольній групі з високим та достатнім рівнем сформованості економічних компетентностей за мотиваційним критерієм, відповідно: 18,1 \% в ЕГ проти 8,3 \% в КГ та $36,1 \%$ в ЕГ проти $18,1 \%$ в КГ. Низький та середній рівень в сумі був характерний лише для $45,9 \%$ студентів в ЕГ проти $73,6 \%$ - в КГ.

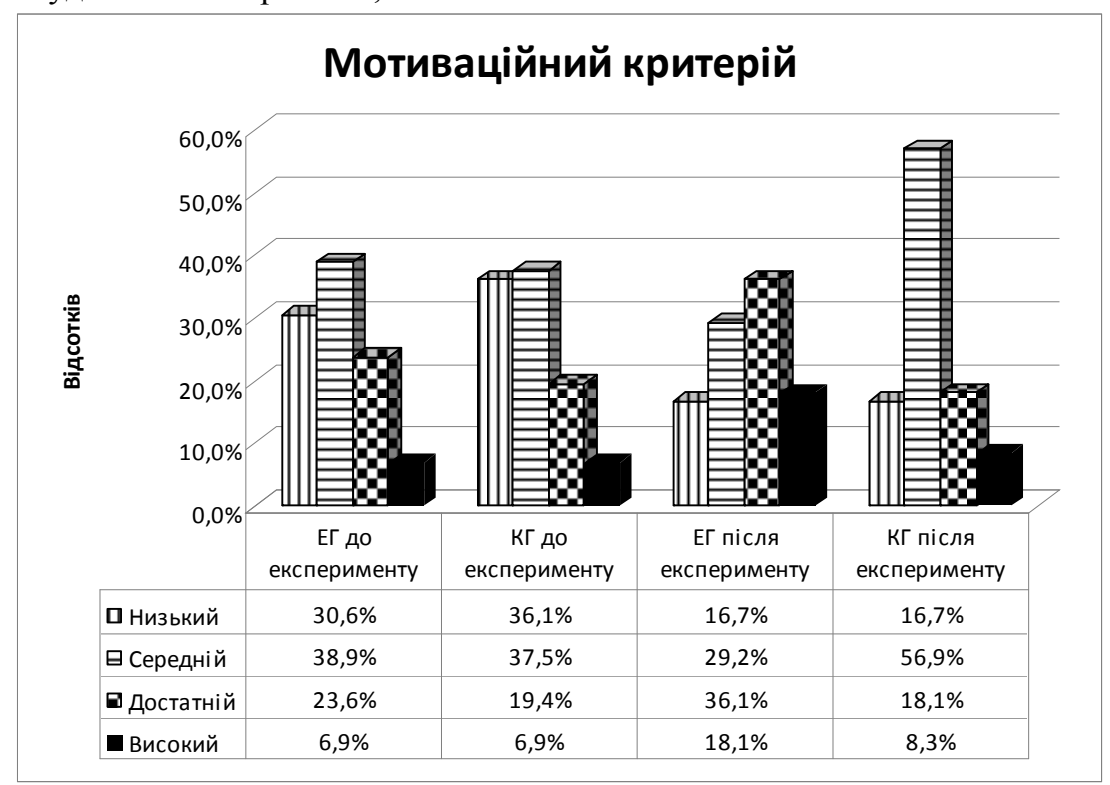

Рис. 1. Динаміка змін економічних компетентностей в КГ та ЕГ за мотиваиійиим критерісм

Оцінка результатів застосування експериментальної методики 3 викориманням програмноімітаційних комплексів економічного спрямування за когнітивним критерієм на формувальному етапі педагогічного експеримента відбувалась шляхом аналізу виконання контрольних завдань МВОК, написання есе 3 тематики, що вивчається, опитування по результатам самостійного опрацювання матеріалу студентами та використання завдань з Тесту на розуміння економіки в коледжі.

За результатами оцінювання сформованості економічних компетентностей за когнітивним критерієм виявлено розподіл рівнів, що наведено в табл. 2. та гістограмі на рис. 2. Значно збільшився відсоток студентів, що оволоділи знаннями в галузі економіки на високому: 19,4 \% в ЕГ проти $11,1 \%$ в КГ; та 
достатньому: 37,5\% в ЕГ проти 12,5\% в КГ рівні. Значно знизився відсоток студентів, економічні компетентності за когнітивним критерієм сформовані на низькому рівні: з 31,9 \% на констатувальному етапі, до 12,5 \% на формувальному етапі педагогічного експерименту.

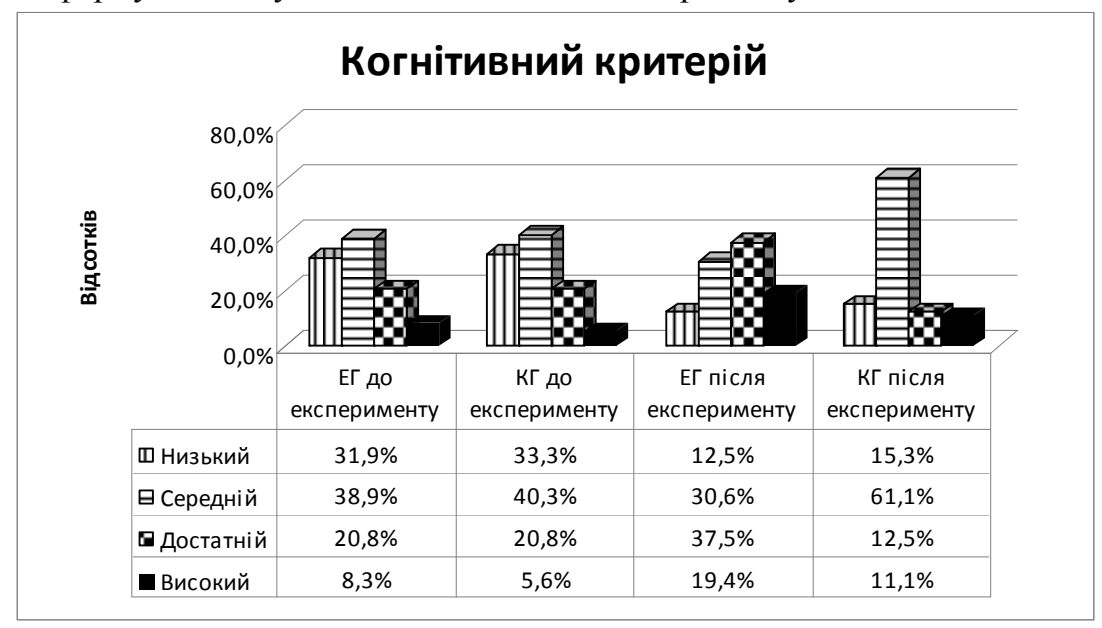

Рис. 2. Динаміка змін економічних компетентностей в КГ та ЕГ за когнітивним критерієм

Для виявлення зміни рівнів сформованості економічних компетентностей студентів за операційним критерієм проводився аналіз виконання контрольних практичних завдань МВОК, виконання практичних завдань з проблемних питань в галузі економіки та персональних фінансів, самостійної підготовки та проведення економічних симуляцій з групою студентів під час практичних занять.

Порівняння рівнів сформованості економічних компетентностей за операційним критерієм наведено в табл. 2. та на рис. 3.

Беручи до уваги такі дані, можемо зробити висновок про значий позитивний вплив застосування експериментальної методики 3 використанням програмно-імітаційних комплексів економічного спрямування на збільшення відсотка студентів експериментальної групи, у яких економічні компетентності за операційним критерієм сформовані на високому та достатньому рівні: 58,3 \% проти 25,2\% у контрольній групі.

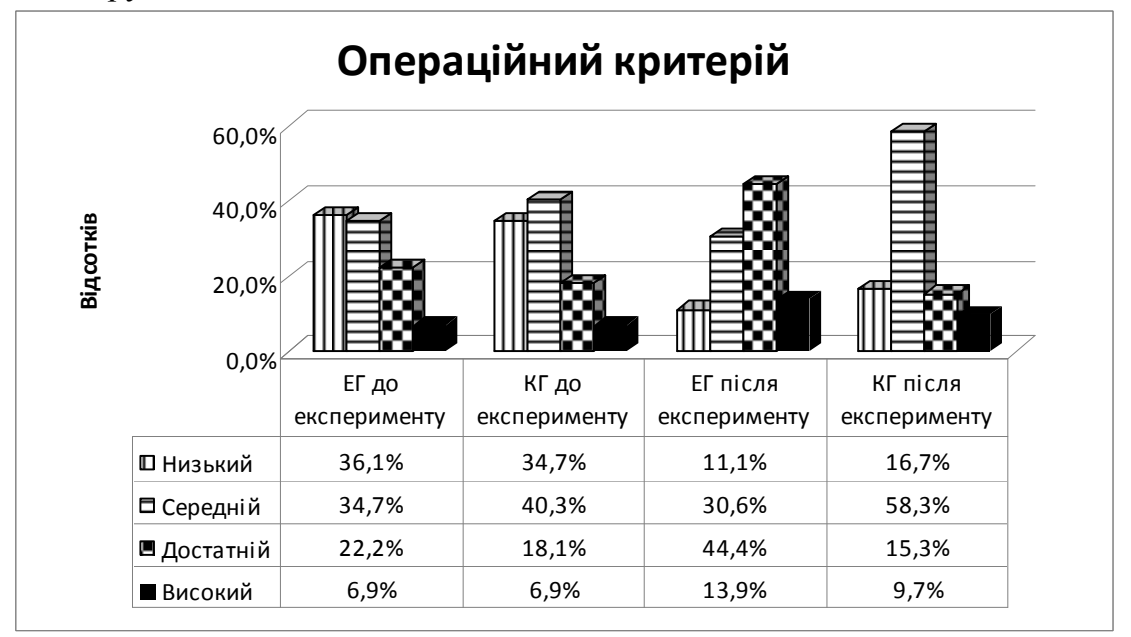

Рис. 3. Динаміка змін економічних компетентностей в КГ та ЕГ за операційним критерієм

Визначення змін рівнів сформованості економічних компетентностей за особистісним критерієм здійснювалось за допомогою використання анкети для визначення рівня сформованості економічних компетентностей студентів технічних спеціальностей за мотиваційним і особистісним критеріями, що заповнювалась студентами наприкінці проходження курсу.

Результати аналізу даних наведено в табл. 2. та на рис. 4.

За результатами заповнення анкети студентами, а також, в процесі педагогічного спостереження при проведення лекційних та практичних занять в заключній частині курсу, у студентів проявляється відмінність сформованості особистого ставлення та з'являються елементи персонального досвіду взаємодії з явищами та процесами соціально-економічної природи. Так, високий і достатній рівень сформованості економічних компетентностей студентів експериментальних груп проявляється в 62,5 \% проти 26,4 \% в контрольній групі. 
У результаті проведення формувального етапу педагогічного експерименту за авторською методикою було відзначено значну кількісну позитивну зміну сформованості економічних компетентностей студентів технічних спеціальностей в розрізі критеріїв в експериментальних групах (див. рис. 5).

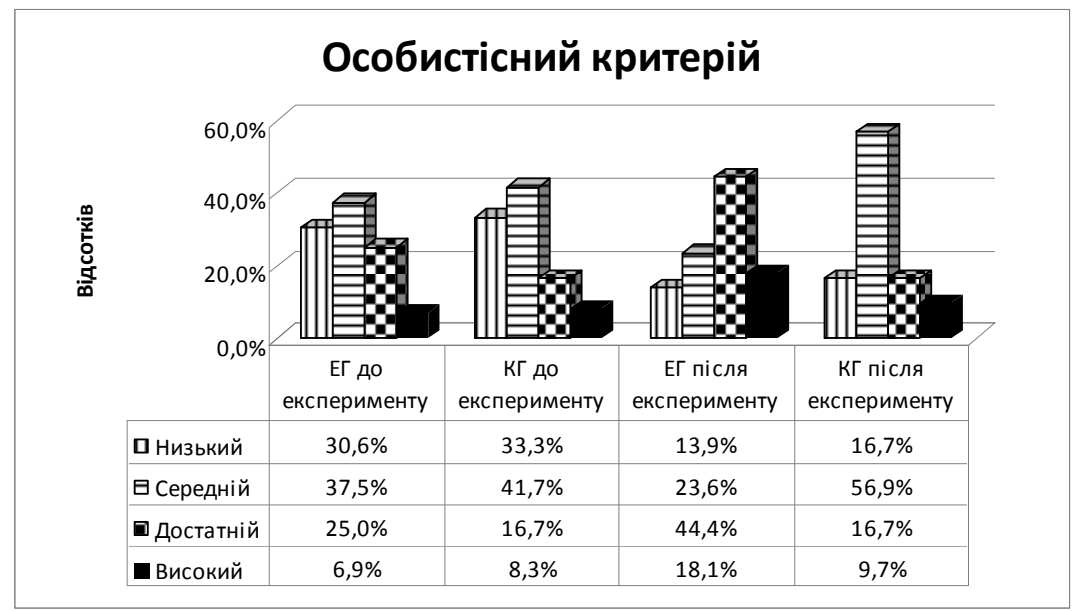

Рис. 4. Динаміка змін економічних компетентностей в КГ та ЕГ за особистісним критерісм

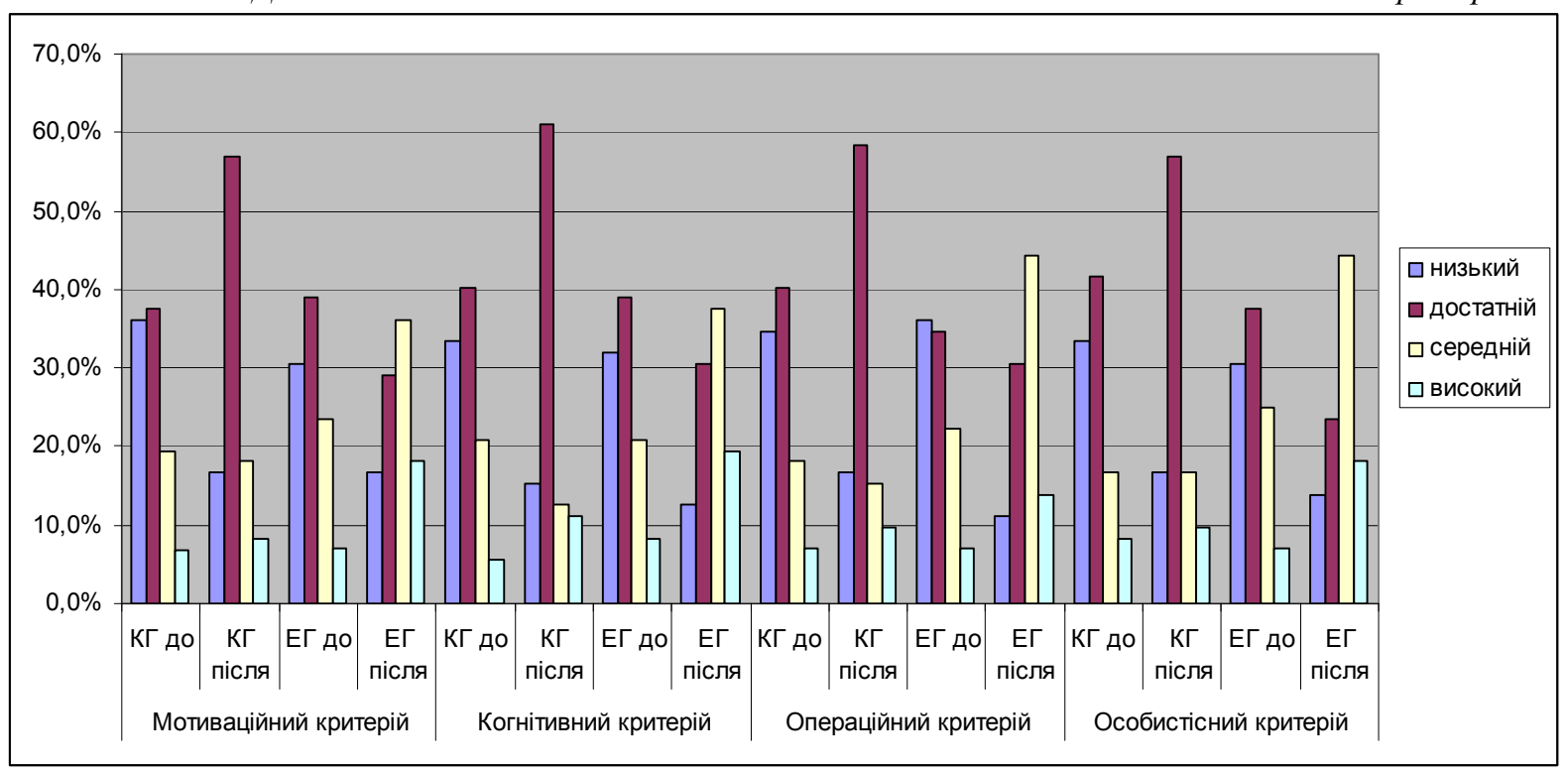

Рис. 5. Динаміка змін економічних компетентностей в КГ та ЕГ за усіма критеріями до та після експерименту

У процесі проходження курсу, в контрольних групах також спостерігалось зростання рівня сформованості економічних компетентностей.

Після завершення формувального етапу педагогічного експерименту проводилось:

- опрацювання отриманих даних;

- аналіз та порівняння результатів дослідження;

- опис проведення та результатів дослідження з використанням статистичних методів обробки даних;

- оформлення та візуалізація результатів дослідження.

Опрацювання результатів аналізу експерименту та оцінка ефективності розробленої методики було здійснено з використанням методів математичної статистики [4]. Задача полягає у виявленні відмінностей в розподілі певної ознаки (сформованості економічної компетентності), тому при порівнянні двох емпіричних розподілів можемо скористатись $\chi 2$-критерієм Пірсона.

Обмеженнями критерію є: вимога до об’єму вибірки $\mathrm{n} \geq 30$; частота для кожної комірки вибірки має бути не менше 5; обрані розряди мають вичерпувати весь розподіл, тобто охоплювати весь діапазон варіативності ознак; якщо одне спостереження віднесене до одного розряду, то воно вже не може бути віднесене ні до якого іншого розряду. Всі ці умови виконуються в отриманих в результаті проведення формувального експеримента вибірках, що підтверджує можливість використання $\chi 2$-критерія Пірсона для опрацювання результатів педагогічного експеримента. 
Нульовою гіпотезою Н0 приймемо твердження, що різниця розподілів значень рівнів сформованості економічних компетентностей студентів технічних спеціальностей в контрольній та експериментальній групах на формувальному етапі експеримента не є статистично значущою.

Альтернативною гіпотезою Н1 приймемо твердження, що різниця розподілів значень рівнів сформованості економічних компетентностей студентів технічних спеціальностей в контрольній та експериментальній групах на формувальному етапі експеримента є статистично значущою.

Оцінка рівнів значущості визначається числом ступенів свободи, що позначається грецькою літерою v і обраховується за формулою $\mathrm{v}=\mathrm{c}-1$, де $\mathrm{c}-$ кількість категорій у вибірці, $\mathrm{k}-$ кількість накладених незалежних умов.

У нашому дослідженні вибірки випадкові і незалежні. Шкалою вимірювань $є$ шкала 3 с $=4$ категоріями (низький, середній, достатній та високий рівні), накладено дві незалежні умови. Отже, кількість ступенів свободи

$\mathrm{v}=\mathrm{c}-1=3$

Нульовою гіпотезою Н0 приймемо твердження, що різниця розподілів значень рівнів сформованості економічних компетентностей студентів технічних спеціальностей в контрольній та експериментальній групах не є статистично значущою. Тобто Н0: p1i=p2i, де (i= \{низький, середній, достатній, високий рівні.

Альтернативною гіпотезою Н1 приймемо твердження, що різниця розподілів значень рівнів сформованості економічної компетентності студентів технічних спеціальностей в контрольній та

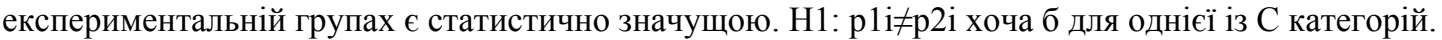

Значення $\chi 2$ обчислюється за наступною формулою:

$$
\chi^{2}=\frac{1}{n_{1} n_{2}} \sum_{i=0}^{C-1} \frac{\left(n_{1} Q_{2 i}-n_{2} Q_{1 i}\right)^{2}}{Q_{1 i}+Q_{2 i}}
$$

$p_{1 i}-\quad$ ймовірність оцінювання рівня сформованості економічних компетентностей студентів технічних спеціальностей учасників КГ на $i$ рівні, де $i$ приймає наступні значення: низький, достатній, середній та високий);

$p_{2 i}-\quad$ ймовірність оцінювання рівня сформованості економічних компетентностей студентів технічних спеціальностей учасників ЕГ на $i$ рівні;

$Q_{1 i}-\quad$ кількість учасників КГ, в яких економічні компетентності сформовані на $i$ рівні;

$Q_{2 i}-\quad$ кількість учасників ЕГ, в яких економічні компетентності сформовані на $i$ рівні.

3 таблиці IX [4: 328] значень $\chi 2$ для рівня значущості $\alpha=0,05$ і кількості степенів свободи $\mathrm{v}=3$ визначаємо критичне значення статистики $\chi 2$ крит $=7,815$.

Провівши обрахування, бачимо, що $\chi 2$ емп $<\chi 20,05$ (7,815), для кожного із критеріїв. Це надає підгрунття для прийняття нульової гіпотези Н0, що дає підстави стверджувати, що ці вибірки не мають статистично значущих відмінностей, тобто можна стверджувати, що якісний склад учасників експериментальної та контрольної груп приблизно рівний на момент початку формувального етапу педагогічного експерименту.

У процесі проведення формувального етапу педагогічного експерименту було введено активний фактор - підготовка студентів 3 використанням авторської методики використання програмноімітаційних комплексів економічного спрямування як засобів формування економічних компетентностей.

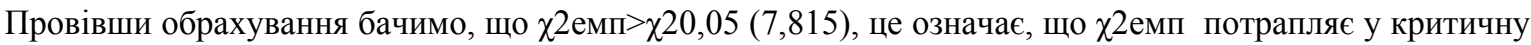
зону для значень вибірок для кожного із критеріїв. Це надає підгрунття для відхилення нульової гіпотези Н0. Прийняття альтернативної гіпотези Н1 дає підстави стверджувати, що ці вибірки мають статистично значущі відмінності, тобто експериментальна методика є ефективною.

Висновки. Результат аналізу проведення педагогічного експерименту підтвердив гіпотезу нашого дослідження щодо того, що використання програмно-імітаційних комплексів при підготовці студентів технічних спеціальностей сприятиме формуванню економічних компетентностей студентів а, отже, ефективність розробленої методики перевірено.

\section{СПИСОК ВИКОРИСТАНИХ ДЖЕРЕЛ ТА ЛІТЕРАТУРИ}

1. Антонюк Д. С. Методичні рекомендації з добору та впровадження програмно-імітаційних комплексів економічного спрямування у навчальний процес ВНЗ / Д. С. Антонюк, Т. А. Вакалюк. - Житомир : Вид-во ФОП "О.О.Свенок", 2018. - 80 с.

2. Антонюк Д. С. Принципи навчання як складова методики формування економічної компетентності студентів технічних спеціальностей з використанням програмно-імітаційних комплексів / Д. С. Антонюк // Матеріали II Всеукраїнської науково-практичної конференції 3 міжнародною участю "Сучасні інформаційні технології в освіті та науці",присвячена 10-ій річниці функціонування Інтернет-порталу ЕOLYMP (09-10 листопада 2017 р., м. Житомир). - Житомир : ЖДУ ім. І. Франка, 2017. - 396 с. - С. 253-256. 
3. Мінтій І. С. Формування у студентів педагогічних університетів компетентностей з програмування на основі функціонального підходу : дис... канд. пед. наук : 13.00.02 / Ірина Сергійївна Мінтій. - К., 2013. - 254 с.

4. Сидоренко Е. В. Методы математической обработки в психологии / Е. В. Сидоренко. - СПб. : Речь, 2003. $350 \mathrm{c}$.

\section{REFERENCES (TRANSLATED \& TRANSLITERATED)}

1. Antoniuk D. S. Metodychni rekomendatsii $\mathrm{z}$ doboru ta vprovadzhennia prohramno-imitatsiinykh kompleksiv ekonomichnoho spriamuvannia u navchalnyi protses VNZ [Methodical Recommendations on Selection and Implementations of Business Simulations to the Educational Process of the Higher Education Institutions] / D. S. Antoniuk, T. A. Vakaliuk. - Zhytomyr : Vyd-vo FOP "O. O. Yevenok", 2018. - $80 \mathrm{~s}$.

2. Antoniuk D. S. Pryntsypy navchannia yak skladova metodyky formuvannia ekonomichnoi kompetentnosti studentiv tekhnichnykh spetsialnostei z vykorystanniam prohramno-imitatsiinykh kompleksiv [Principles of Teaching as the Part of Economic Competence Methodic of Technology Specialties Students Formation] / D. S. Antoniuk // Materialy II Vseukrainskoi naukovo-praktychnoi konferentsii z mizhnarodnoiu uchastiu "Suchasni informatsiini tekhnolohii v osviti ta nautsi", prysviachena 10-ii richnytsi funktsionuvannia Internet-portalu E-OLYMP [Materials of the 2-nd Ukrainian Scientifically-Practical Conference with International Participation "Modern Information Technologies in Education and Science", Dedicated to the 10-th Anniversary of E-OLYMP Internet-Portal] (09-10 lystopada 2017 r., m. Zhytomyr). - Zhytomyr : ZhDU im. I. Franka, 2017. - 396 s. - S. 253-256.

3. Mintii I. S. Formuvannia u studentiv pedahohichnykh universytetiv kompetentnostei z prohramuvannia na osnovi funktsionalnoho pidkhodu [Formation of Competencies in Software Development of the Students of Pedagogical University Based on Functional Approach.] : dys... kand. ped. nauk [PhD dissertation]: 13.00.02 / Iryna Serhiiivna Mintii. - K., 2013. - $254 \mathrm{~s}$.

4. Sydorenko E. V. Metody matematycheskoi obrabotky $v$ psykholohyy [Methods of Statistic Processing in Psychology] / E. V. Sydorenko. - SPb. : Rech, 2003. - 350 s.

\section{Антонюк Д. С. Эффективность использования программно-иммитационных комплексов как средства формирования экономической компетентности студентов технических специальностей по результатам педагогического эксперимента.}

В статье представлены результаты педагогического эксперимента относительно эффективности использования программно-иммитаџионных комплексов как средства формирования экономической компетентности студентов технических специальностей. Согласно полученным данным, эффективность методики была подтверждена, так как наблюдается увеличение уровня сформированности экономических компетентностей студентов технических специильностей.

Ключевые слова: педагогический эксперимент, эффективность, экономическая компетентность.

\section{Antoniuk D. S. Efficiency of the Use of Business Simulations as a Means for Formation of Economic Competence of Technical Specialties Students According to the Results of Pedagogical Experiment.}

Determining the quantitative effects of the qualitative pedagogical influences requires the proven tools and approaches to be used. The article describes the results of pedagogical experiment which assesses the efficiency of the use of business simulations as a means for formation of economic competence of technical specialties students. Analysis of the publications on the topic of economic competence formation and the use of business simulations for this purpose is provided. The type of educational methods and activities that were used during the experiment is listed. The way the experimental group and control group were formed is described. The use of the methods of mathematical statistics that proved the experimental and control groups were formed avoiding statistically significant differences of the levels of economic competency. The methods of mathematical statistics

also proved the final results of the students from the experimental group and control group. They have

statistically significant differences. The proposed author's methodic proved to be efficient according to the received results due to the fact of higher level of economic competence growth. It was shown by the students of experimental group in comparison to the control group.

Key words: pedagogical experiment, efficiency, economic competence. 